\title{
On the Issue of Commercial Insurance and Commercial Insurance Market in the Slovak Republic
}

\author{
Barbora Drugdová \\ University of Economics in Bratislava, Bratislava, Slovak Republic
}

\begin{abstract}
The article is concentrated on the Slovak commercial insurance, commercial insurance market, non-life insurance, and international risks on the Slovak Republic. Since 1 May 2004, the Slovak insurance market has been part of the uniform European Union insurance market, which includes over 5,000 insurance companies. After Slovakia's admission to the European Union, several legislative changes have been adopted in the area of commercial insurance industry, which also influenced non-life insurance and the insurance of international risks as part of non-life risks. The most recent act in the area of commercial insurance mentioned in the paper is the Act of the National Council SR No. 39/2015 Coll. on Insurance, in which there are legislative changes in life and also non-life insurance. Basic terms are defined and commented on in the first two chapters (Lowry, Rawlings, \& Merkin, 2015). The nature of international risks as part of non-life risks is described in the second chapter. International risks are classified in the third chapter; international risks are subdivided in the paper into commercial or trade risks, political and economic risks, and special types of risks.
\end{abstract}

Keywords: insurance, commercial insurance market, non-life insurance, classification of international risks, political and economic risks, and special types of risks, insurance non-life market in Slovak Republic

\section{Introduction}

Insurance and the insurance industry extend directly or indirectly to all areas of human activities, and so they affect each firm, enterprise, citizen, entire society; all the changes in society are reflected in some way also in insurance activity (Bland, 2003). Development of science, technology, and culture brings to the market new modern products, new activities, and thus also new risks. Enterprises and businesspeople, citizens, state, as well as insurance companies have to take into consideration and calculate with these risks. Consequently, commercial insurance companies have to constantly prepare new insurance products related to life and non-life risks for the commercial insurance market and simultaneously monitor the development in the entire economy (e.g. GDP development, unemployment growth, inflation, growth of prices, movement of money/pecuniary incomes, demographic data, and other macro- and micro-economic indicators).

\section{Description of Non-life Risks}

Non-life insurance is an insurance that includes a broad range of risk of non-life type. In the literature, we

Barbora Drugdová, Ing., Ph.D., Department of Insurance, Faculty of National Economy, University of Economics in Bratislava, Bratislava, Slovak Republic.

Correspondence concerning this article should be addressed to Barbora Drugdová, Department of Insurance, Faculty of National Economy, University of Economics in Bratislava, Dolnozemska Rd. 1/a, Bratislava 852 35, Slovak Republic. 
can find various definitions of the essence of non-life insurance.

Non-life risks can be divided into four groups: The first group includes risks that present danger to health and lives of persons - e.g. accident (casualty), illness, disability, and the like. The second group includes risks that cause financial losses - credit risks, legal risks, risks of financial losses, liability risks, and the like. The third group contains risks producing direct material losses - elemental risks, theft, vandalism, and the like. The fourth group includes international risks. Non-life insurance is short term, i.e. the insurance contract is closed for an indefinite duration with a yearly insurance period, or one that is shorter than a year in contrast to life insurance contracts which are long term and are closed for a definite duration (Drugdová, 2016). The insurance contract constitutes a bilateral legal document, which is a basis of contractual relation between the insurer and the insurant. In it, the insurer pledges to provide within a negotiated extent the insurance premium, if an accidental insurance event arises, which is stipulated in the insurance contract, and the insurant takes a pledge to pay the insurance premium.

\section{Description of International Risks as Part of Non-life Risks}

Economic relations arising between two or more states bring a lot of new risks but also the opportunities of forecasting, reducing, and eliminating them. Many of these risks pass from one state into another, e.g. price fluctuations, inflation development, and the like. On the other hand, some risks are enabled to refrain from and eliminate numerous difficulties of a different kind, e.g. import of shortage of raw materials and materials, thus supporting the development of production while enabling the expansion of exports and the like (Harington \& Nielhaus, 1999).

In professional foreign and domestic sources available, we encounter with the classification of international risks as part of non-life risks in the area of non-life insurance, which are connected with international commercial relations. We understand the concept of international risks as the risks arising outside the territory of a given state.

The problems of international risks are extensive and comprehensive in terms of diversification of the cases in terms of export, re-export, or import; from numerous aspects, including commercial, legal, technical, banking and financial ones, as well as from broader political and economic connections (Drugdová, 2016).

The most frequent classification is that into three groups of international risks, the focus will be on them in the present paper, namely: commercial risks, political and economic risks, and other types of risks.

\section{Classification of International Risks}

International risks are classified in non-life risks. International risks are divided into commercial or trade (financial) risks, political and economic risks, and special types of risks.

\section{Classification of Commercial Risks}

Commercial risks create a system of larger and smaller risks, relating to mainly trade-and-finance transfers.

The intensity of commercial risks is stronger in external relations than in internal economy of countries, mainly due to the following reasons:

(1) Difference in mentalities is accompanied with a limited communicative competence, but also with difficulties in searching for new markets. 
(2) Language barriers involve the danger of misunderstanding or wrong interpretations in closing contracts, which may result in negative consequences.

(3) Differences in legal systems may lead to the situation when the contract is interpreted according to the law and commercial usage of the exporter as well as the importer. Awards of the courts concerned are hard to enforce abroad and may be more expensive than the subject-matter of the dispute.

(4) A larger distance between contractual parties, which results in less mutual knowledge, worse orientation in a foreign market, and also in a higher transportation risk.

(5) Commercial risks in contractual relations ensue from the danger that the foreign partner fails to adhere to the contract closed either because it is not willing to do so, or because the party concerned is unable to stand by the contract. The inability of the partner to fulfil commitments resulting from the contract is, as a rule, caused by the change in the economic position or in an unrealistic estimate of their economic possibilities (Drugdová, 2016).

The intensity of the impact of commercial risks on individual operations abroad is, in general, given by two factors:

(a) The first factor is the partner's reliability - it is possible to assess the legal position of the partner from this aspect, the partner's proprietary condition, commercial efficiency, technical and economic conditions of fulfilling the commitment, and the like.

(b) The second factor is a degree of legal protection of a given contractual relation - it is as a rule the case of legal perfection of the contract, its terms and conditions, the law according to which the legal relation is assessed, character of sanctions for non-fulfilment of the contract.

Commercial risks are kinds of risks, which can affect the results achieved mainly in the negative direction. They are one of the few kinds of risks in which the protection can be applied via their minimisation. These risks are influenced by the quality of work of entities in the sphere of foreign economic relations, their ability to appraise risks and choose suitable ways of their restriction.

\section{Classification of Political and Economic Risks}

Political risks ensue from an overall political, economic, and financial situation of the country to into which exports directed.

The concept of political risk is in general connected with an immediate threat to profit; in extreme cases it also involves the danger of the economic existence of foreign companies, or even also international enterprises. The reasons for the rise of political risks result from changes in the political environment of an enterprise. They are materialized by means of measures adopted by the state, and these mean for the exporter the risk of non-ratification or cancellation of the contract, embargo of export, non-performance of foreign exchange transfer, confiscation of materials and products, and the like.

From the broadest perspective, this risk results from hostile activities, e.g. war, revolution, strikes, commotions, civil wars, etc. Political and economic risks in international trade can no longer be considered to be external risks. These risks cannot be generally underrated. It is necessary to calculate the deal. An immense indebtedness of the developing world, extensive financial insolvency, international debt crisis, dangerous and explosive situation in many world regions, all these factors just strengthen and emphasize the necessity to decrease political and economic risks.

Political and economic risks are classified into the following kinds: 
(1) Exchange risk - the money that the importer has already paid at their bank cannot be (temporarily) exchanged for any other foreign currency as a result of government measures of an importing country as well as due to shortage of foreign exchange.

(2) Moratorium - settlement and transfer of the amount due to the exporter will not be permitted by the state at the time of debt maturity, but will allow only partial payment of the debt, or the deferral of payment will be directed.

(3) Transfer risk - the money paid by the importer at the bank cannot be (partially or completely) transferred abroad, because the importing country refuses to permit this kind of transfer for economic and political reasons.

The risk of transfer involves the danger of a complete or partial restriction of the transfer of profit, material goods, know-how, licence fees, payment for services s well as of capital.

\section{Special Kinds of Risks as Part of International Risks}

Special kinds of risks constitute a separate group of international risks. This group includes the following risks: exchange rate risk, risks of interest rate fluctuation, inflation risk, legal risk, foreign investment risks, natural and technical disasters/catastrophes, risks of terrorist attacks, and specific risks. We can include the following risks in the group of specific risks: specific risks of certainty, safety, covering events that present danger to our health, freedom, and life of employees of international companies and institutions, as well as of family members, and apprehensions to the future. Everyday reality persuades us about a rising "capability" of man or a group of people who have to be nationalistic, ideological, religious, sectarian, or even terrorist inclinations, who pose a threat to not only property but also health and lives of innocent people (Sivák, 2015). A rising number of terrorist attacks on the threshold of the millennium cannot leave calm all peace-loving people on this planet. We can mention also more severe attacks, e.g. attack in the United States in 2001, or in Spain in the year 2004, and other terrorist attacks mainly in the US, Great Britain as well as in third countries.

\section{Insurance of International Risks as Part of Non-life Risks on the Slovak Commercial Market}

On the Slovak commercial insurance market, the insurance of international risks as part of non-life insurance belongs to the province of commercial insurance companies, which are associated in the Slovak Association of Insurers.

Numerous commercial insurance companies operate on the commercial insurance market in advanced economies. Each of them participates in this market with a different offer of insurance products and attempts to cover the largest possible space (insurance field). ${ }^{1}$ As on 31 December 2015 as mentioned before, as many as twenty-one commercial insurance companies operated on the Slovak insurance market; all of them were associated in the Slovak Association of Insurers and recorded technical insurance premium indicators as shown in Table 1 (Table 1: The total of technical premium and technical insurance premium in non-life insurance as on 31 December 2015 in thousand of Euros). Commercial insurance companies offering insurance products in the area of international risks participated in non-life insurance with the following data.

\footnotetext{
${ }^{1}$ Commercial insurance companies offer on the insurance market insurance products of life and non-life insurance. Non-life insurance products are more numerous, this is due to the fact that the number of risks of non-life character is higher in economic practice. These risks also include international risks.
} 
Table 1

Technical Premium in Total and in Non-life Insurance in Commercial Insurance Companies as on 31 December 2015 in Thousand $€^{2}$

\begin{tabular}{|c|c|c|c|}
\hline No. & Commercial insurance company & $\begin{array}{l}\text { Technical premium } \\
\text { total for all insurance } \\
\text { products }\end{array}$ & $\begin{array}{l}\text { Technical premium in } \\
\text { nonlife insurance for } \\
\text { insurance products }\end{array}$ \\
\hline 1 & Aegon Life Insurance company & 42,092 & 0 \\
\hline 2 & Allianz-Slovenská Insurance company, a. s. & 586,308 & 333,118 \\
\hline 3 & $\begin{array}{l}\text { AXA Life Insurance company, branch of an insurance company in } \\
\text { another member state }\end{array}$ & 52,524 & 5,519 \\
\hline 4 & $\begin{array}{l}\text { AXA Insurance company branch of an insurance company in another } \\
\text { member state }\end{array}$ & 10,226 & 10,226 \\
\hline 5 & $\begin{array}{l}\text { BASLER Lebensversicherung-AG branch of an insurance company } \\
\text { in another member state }\end{array}$ & 5,838 & 0 \\
\hline 6 & $\begin{array}{l}\text { BASLER Sachversicherung-AG branch of an insurance company in } \\
\text { another member state }\end{array}$ & 4,067 & 4,067 \\
\hline 7 & ČSOB insurance company, a. s. & 80,870 & 28,170 \\
\hline 8 & $\begin{array}{l}\text { D.A.S. Rechtsschutz AG, branch of an insurance company in another } \\
\text { member state }\end{array}$ & 2,643 & 2,643 \\
\hline 9 & ERGO Insurance company, a.s. & 34,082 & 1,563 \\
\hline 10 & Generali Slovakia Insurance company, a. s. & 174,000 & 95,669 \\
\hline 11 & $\begin{array}{l}\text { Groupama Garancia Insurance company, a.s., branch of an insurance } \\
\text { company in another member state }\end{array}$ & 4,514 & 3,992 \\
\hline 12 & ING Life Insurance company, a. s. & 75,951 & 0 \\
\hline 13 & KomunÁLNA Insurance company, a. s. VIG & 176,840 & 66,401 \\
\hline 14 & Kooperativa Insurance company, a. s., VIG & 477,673 & 255,111 \\
\hline 15 & MetLife insurance company, a.s. & 124,738 & 8,964 \\
\hline 16 & Cardif Slovakia, Insurance company a.s. & 23,049 & 16,834 \\
\hline 17 & Insurance company of the Poštová Banka, a. s. & 10,805 & 1,148 \\
\hline 18 & Insurance company of the Slovenská Sporitel'ňa, a. s., VIG & 80,632 & 0 \\
\hline 19 & UNION insurance company, a. s. & 40,946 & 31,185 \\
\hline 20 & UNIQA insurance company, a. s. & 112,723 & 80,641 \\
\hline 21 & Wüstenrot insurance company & 60,371 & 22,093 \\
\hline \multirow[t]{2}{*}{22} & Slovak Insurers Office & 8 & 8 \\
\hline & Total & $2,180,899$ & 965,351 \\
\hline
\end{tabular}

The total of technical insurance premium for all insurance products in the year 2015 was 2,180,899 thousand Euros. Table 1 entitled "Technical Premium in total and in nonlife insurance in commercial insurance

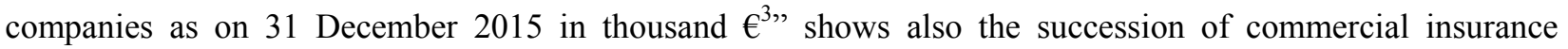
companies on the Slovak insurance market in the year 2015. The primacy in non-life insurance on the Slovak insurance market was held by Allianz-Slovenská Poist'ovňa, a. s., with 34.51\%, which accounted for 333,118 thousand Euros. The second place was occupied by KOOPERATÍVA insurance company, a.s., VIG in non-life insurance with $26.43 \%$, which accounted for 255,111 thousand Euros, and the third place in non-life insurance by Generali Slovensko, insurance company, a.s. with 9.91\%, which is equal to 95,669 thousand Euros.

\footnotetext{
2 Source: www.slaspo.sk.

3 Source: www.slaspo.sk.
} 
Insurance products designed for insuring international risks belong to the area of non-life insurance. The insurance company Allianz-Slovenská Poist'ovňa, a. s. has the widest offer of insurance products designed for the insurance of international risks. In the year 2015 the commercial insurance company Allianz-Slovenská Poist'ovňa, a.s. achieved primacy in the total technical insurance premium for all the insurance products, which amounted to 586,308 thousand Euros and reached $26.88 \%$ share of the total commercial insurance market.

The most important insurance products in the area of international risks offered by commercial insurance companies on the commercial insurance market are: transportation insurance (insurance of international transportation of consignments), insurance of investment unit (building and assembly insurance), insurance of exhibitions and fairs, product liability insurance, insurance of international road carrier, motor hull insurance for travel abroad, aircraft operation insurance, and special risks insurance. Special risks include mainly: insurance of equipment of nuclear industry and of allied perils, export credit insurance, insurance of caution money, insurance of early delivery of goods to a foreign buyer, and insurance of shipping charges.

Another group, which we classify in the area of international risks relates to insurance of persons, namely: insurance of tourist risks, tourism insurance, insurance of medical expenses incurred abroad, and the like.

\section{Conclusions}

In connection with the insurance of international risks, as part of non-life risks, it has to be mentioned that commercial insurance companies on the Slovak insurance market do not offer some insurance, which are used in European Union countries, in particular in Great Britain, Germany, and France, and in the entire advanced world, mainly in Japan and in the United States of America. They are in particular insurance products from the area of commercial risks (e.g. banking and financial risks) and also insurance products that belong to the special kinds of risks (e.g. natural catastrophes risks and technical disasters, as well as risks of terrorist attacks and the like.)

\section{References}

Bland, D. (2003). Insurance principles and practice. London: The Chartered Insurance Institute. Drugdová, B. (2016). Insurance non-life risks (p. 184). Bratislava: ŠEVT Publisher. Harington, S. E., \& Nielhaus, G. R. (1999). Risk management and insurance (p. 218). Irwin: McGraw-Hill. Lowry, J., Rawlings, P., \& Merkin, R. (2015). Insurance law: Doctrines and principles (p. 389). Oxford, UK: Hard Publishing. Sivák and team (2015). Financie (p. 457). Bratislava: Wolters Kluwer Publisher. 